
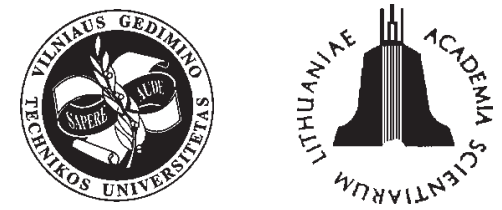

ISSN 1392-3730

JOURNAL OF CIVIL ENGINEERING AND MANAGEMENT

http:/www.jcem.vgtu.lt

2005, Vol XI, No 3, 217-224

\title{
COMPONENT METHOD EXTENSION TO STEEL BEAM-TO-BEAM AND BEAM-TO-COLUMN KNEE JOINTS UNDER BENDING AND AXIAL FORCES
}

\author{
Kęstutis Urbonas ${ }^{1}$, Alfonsas Daniūnas ${ }^{2}$ \\ Dept of Steel and Timber Structures, Vilnius Gediminas Technical University, Saulètekio al. 11, \\ LT-10223 Vilnius, Lithuania

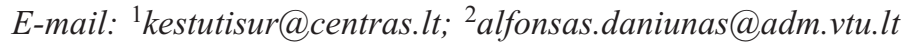

Received 06 Apr 2005; accepted 23 June 2005

\begin{abstract}
This paper presents an analysis of semi-rigid beam-to-beam end-plate bolted and beam-to-column end-plate bolted knee joints that are subjected to bending and tension or compression axial force. Usually the influence of axial force on joint rigidity is neglected. According to EC3, the axial load, which is less than $10 \%$ of plastic resistance of the connected member under axial force, may be disregarded in the design of joint. Actually the level of axial forces in joints of structures may be significant and has a significant influence on joint rigidity. One of the most popular practical method permitting the determination of rigidity and strength of joint is the so-called component method. The extension of the component method for evaluating the influence of bending moment and axial force on the rigidity and strength of the joint are presented in the paper. The numerical results of calculations of rigidity and strength of beam-to-beam and beam-to-column knee joints are presented in this paper as well.
\end{abstract}

Keywords: steel structures, semi-rigid joints, beam-to-beam joints, beam-to-column knee joints, bending and axial forces, component method, moment-rotation curve, strength.

\section{Introduction}

One of the possibilities to improve the accuracy of steel structures analysis can be an evaluation of the actual behaviour of joints. For these purposes the semirigid joint conception was introduced.

The most relevant influence on the rigidity of the joint is produced by bending moments. In this case the behaviour of a semi-rigid joint is described by momentrotation $M-\Phi$ curve of the joint. This conception is adopted by most researchers [1-6]. The joints are also influenced by axial and shear forces. These forces usually are not evaluated in calculating the rigidity and strength of the joints.

According to EC3 [7, 8], the axial load less than $10 \%$ of plastic resistance of the connected member under axial force may be disregarded in the joint design. There are many different types of joints in which axial forces may be significant and influence the joint rigidity and strength. The influence of axial force on the rigidity and strength characteristics of the joint has not been analysed widely. It was noticed in some articles that the axial force affects the joint structural behaviour. All researchers who had investigated this topic made the same conclusion: the axial force influences the behaviour of the joint and this influence must be taken into account [9-11].
Various methods are used for establishing force-displacement curves of semi-rigid joints: empirical, analytical, mechanical, numerical and experimental tests [1]. The most common analytical method applied in practice is the component method. It estimates mechanical properties of the material and geometrical properties of joint and allows predicting the behaviour of joint types $[1,7$, 8, 12].

This paper presents extension of the component method to semi-rigid beam-to-beam end-plate bolted and beam-to-column end-plate bolted knee joints under bending and axial forces. The main focus is made on estimation of axial force influence in addition to bending moment influence on the joint rigidity and strength. The numerical results of beam-to-column knee-joints calculations also have shown the influence of beam inclination on the joints behaviour. The comparison of the results of some analysed joints calculated according to the applied procedure and obtained by the finite element method is presented in this paper too.

\section{Formulation of problem}

The structural joints of steel are subjected by bending moments, axial and shear forces. The influence of these forces on joint behaviour mostly depends on joint type. From the practical point of view, the investigation 


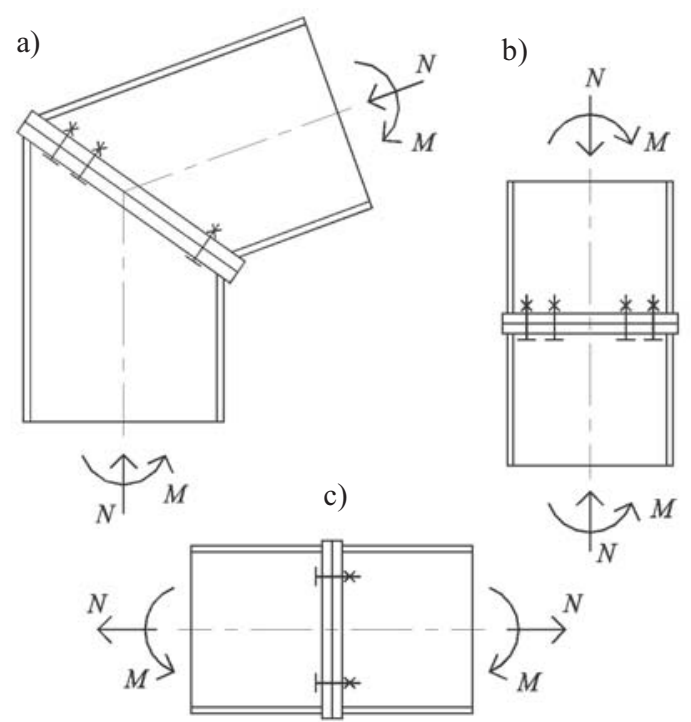

Fig 1. Semi-rigid end-plate joints under bending and axial forces: a) beam-to-column knee joint; b) column-to-column joint; c) beam-to-beam joint

of bending moment and axial force common influence on joint rigidity and strength is important for end plate beam-to-column knee, column-to-column and beam-tobeam joints (Fig 1). Notice that column-to-column and beam-to-beam joint behaviour under bending moment and axial force is very similar. Usually the title of joint depends upon its position in the whole structure.

The aim is to compound the procedure, which evaluates the behaviour of these joints under the bending moment and axial force. This evaluation is based on the component method application to steel joints.

The evaluation of the joint's behaviour in the component method consists of three steps: identification of the component, evaluation of the mechanical properties of the components and assembling active components to one mechanical model [11].

Joints which are subjected to bending moments and axial force partition into components and calculation of components rigidity and resistance are the same as in making calculation of the joints characteristics taking into account only the bending moment. Difference is only in forces that fall on the joint components. These forces determine the variation of rigidity and resistance of the joint.

\section{Description of component method for moment re- sistance joints}

Usually only rotational deformation is considered for moment resistance joints. The behaviour of a semi-rigid joint is described by moment-rotation $M-\Phi$ curve of the joint. Other acting forces are not evaluated in joint rigidity calculations.

According to the component method, the rotational stiffness of the joint must be determined by its basic components. The component method allows to charac-

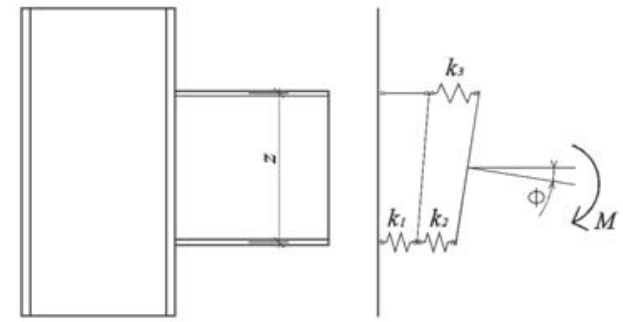

Fig 2. Mechanical model of an unstiffened welded joint under bending

terise all the components of the joint independently of the loading type. Each component is represented by elastic stiffness coefficient, which belongs only to mechanical and geometrical data of the joint. A key aspect of the component method relates to the characterisation of force-deformation relationship for each component [13]. Fig 2 shows an example of the mechanical model for an unstiffened welded beam-to-column joint.

The force-deformation relationship of the component $i$, which is represented by a spring, is given by

$$
F_{i}=k_{i} \cdot E \cdot \Delta_{i}
$$

where $F_{i}$ - the force in the spring $i, k_{i}$ - the stiffness coefficient of the component $i, E-$ the Young modulus, $\Delta_{i}$ - deformation of the spring $i$.

The rotation of the joint can be found by the following formula:

$$
\Phi=\frac{\sum \Delta_{i}}{z},
$$

where $\sum \Delta_{i}-$ total deformation of all components $i, z-$ the lever arm.

In this case initial stiffness of the joint is expressed by:

$$
S_{j, i n i}=\frac{M}{\Phi}=\frac{F \cdot z}{\frac{\sum \Delta_{i}}{z}}=\frac{F \cdot z^{2}}{\frac{F}{E} \sum \frac{1}{k_{i}}}=\frac{E \cdot z^{2}}{\sum \frac{1}{k_{i}}} .
$$

The weakest component of the joint determines the joint resistance:

$$
F_{R d}=\min \left[F_{R d, i}\right],
$$

where $F_{R d, i}$ - resistance of component $i$.

The moment resistance of the joint is determined by:

$$
M_{R d}=F_{R d} \cdot z .
$$

\section{The evaluation of axial force and bending moment in joints by component method}

The behaviour of joints loaded by bending moment and axial force can be described by $M-\mathrm{F}-N$ curves. Beamto-beam knee and beam-to-beam joint in which the beam of symmetrical cross-section is connected to another one 
a)
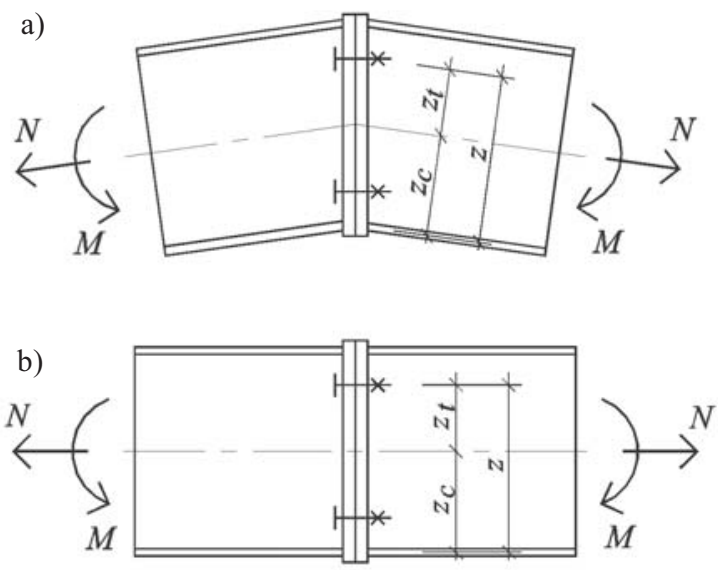

c)

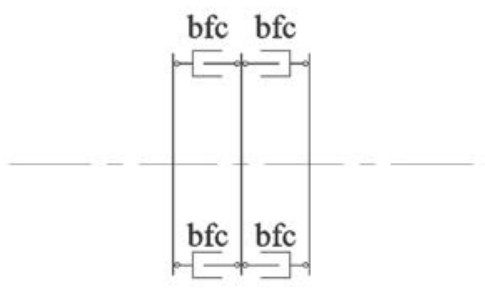

d)

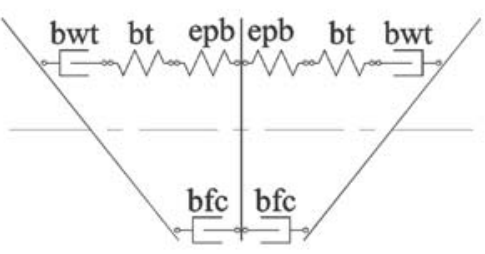

e)

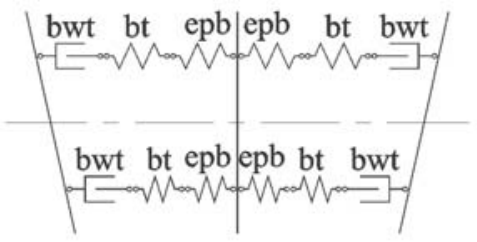

Fig 3. Loading schemes and mechanical models of joint: a) beam-to-beam knee joint; b) beam-to-beam joint; c) both sides of the connection in compression; d) upper part of the connection in tension and lower part in compression; e) both sides of the connection in tension

through the end plates by bolts was analysed (Fig 3). Despite the beam inclination, the behaviour of beam-tobeam knee joint is alike to the beam-to-beam joints. It must be noted that components of these types of joints are the same $[6,7]$.

Deformability of beam web in tension (bwt) and beam flange in compression (bfc) is negligible and these components are considered as rigid-plastic ones influencing only the joint resistance. The end plates in bending (epb) and bolts in tension (bt) are simulated as elastic-plastic springs and they influence the joint stiffness $[1,7]$.

Under the axial force, the behaviour of the joint changes [11]. Axial force increases or decreases in components receivable from bending moment. If the axial force compresses, the compressed components have to resist higher compression than in case when the joint is loaded only by bending moment and vice versa. In some loading situations, only tension forces or only compression forces act. Alongside with the changing forces, deformation of components changes as well and affects the joint rotational capacity. In such a way the axial force influences the joint behaviour.

Mechanical model of the joint depends upon values and directions of acting forces (Fig 3). In case of compression of both sides of the connection, there were no components under tension. Therefore there is only one active component in strength calculations, namely beam flange in compression.

All components mentioned in this chapter must be evaluated, when one part of the connection is loaded by tension force and the other by compression. When both connection sides are under tension, all the mentioned components, except for beam flange in compression, have to be evaluated. Mechanical models would be specular when bending moments act in a contrary direction.

The component stiffness does not depend on acting forces. It means that the stiffness coefficients of the components in bending and axial loading must be determined in the same way as the joint loaded only by bending moment. Therefore stiffness coefficient of each component, independent of acting forces, will be the same and determined by well-known rules in the component method. It is worth mentioning that some information sources show different coefficients, but all the members of these formulas are the same [1, 7].

Maximal compression force in components, when both sides of the connection are in compression (Fig 3, c), can be expressed by:

$$
F_{c, \text { max }}=\frac{M}{2 z_{c}}-\frac{N}{2},
$$

where $N$ - compression axial force (positive axial force $N$ is tension axial force), $z_{c}-$ distance between the centre of the cross-section of the beams and the compression centre, which is in the centre of the beam lower flange.

In this case tension deformations equal zero. Therefore the joint flexibility equals zero as well. It means that the joint in such a type of loading is ideally rigid.

Tension and compression forces in components, when one part of the connection is under tension and the other under compression (Fig 3, d), can be expressed by:

$$
\begin{aligned}
& F_{t, i}=\frac{M}{z}+\frac{N \cdot z_{c}}{z}, \\
& F_{c}=\frac{M}{z}-\frac{N \cdot z_{t}}{z},
\end{aligned}
$$

where $z$ - the lever arm, $z_{t}$ - distance between the centre of the cross-section of the beams and the tension centre.

Deformation of component $i$ under tension can be found by the formula derived from (1) and substituting expression (7): 


$$
\Delta_{t, i}=\frac{\frac{M}{z}+\frac{N \cdot z_{c}}{z}}{E \cdot k_{t, i}}=\frac{M+N \cdot z_{c}}{E \cdot z \cdot k_{t, i}} .
$$

The rotation of the joint depends on the deformation of all tensed components $i$ :

$$
\Phi=\frac{\sum \Delta_{t, i}}{z}
$$

The initial stiffness of the joint is expressed by ratio between bending moment and rotation of the joint:

$$
S_{j, i n i}=\frac{M}{\Phi}=\frac{M \cdot z}{\sum \Delta_{t, i}}
$$

Maximal and minimal tension forces in components when both sides of the connection are under tension forces (Fig 3, e) can be expressed by:

$$
\begin{aligned}
& F_{t, \max , i}=\frac{N}{2}+\frac{M}{2 z_{t}}, \\
& F_{t, \min , i}=\frac{N}{2}-\frac{M}{2 z_{t}},
\end{aligned}
$$

where $N$ - tension axial force.

Indexes max and min indicates the cross-section parts that are in maximal and minimal tension.

Deformation of component can be found by the formulas derived from (1) and (11):

$$
\begin{aligned}
& \Delta_{t, \max , i}=\frac{\frac{N}{2}+\frac{M}{2 z_{t}}}{E \cdot k_{t, \max , i}}=\frac{N+\frac{M}{z_{t}}}{2 E \cdot k_{t, \max , i}}, \\
& \Delta_{t, \min , i}=\frac{\frac{N}{2}-\frac{M}{2 z_{t}}}{E \cdot k_{t, \min , i}}=\frac{N-\frac{M}{z_{t}}}{2 E \cdot k_{t, \min , i}},
\end{aligned}
$$

where $\Delta_{t, \max , i}-$ maximal tension deformation of component $i, \Delta_{t, \min , i}-$ minimal tension deformation of component $i$.

The initial stiffness of the joint in analogous way for this loading can be expressed by:

$$
S_{j, \text { ini }}=\frac{M}{\Phi}=\frac{2 z_{t} M}{\sum \Delta_{t, \max }-\sum \Delta_{t, \min }} .
$$

The above procedure for stiffness calculation is proper only in case, when the structure is elastic, consequently the moment-rotation $M-\Phi$ curve is up to such a bending moment where physical non-linearity does not occur. According to EC3, the physical non-linearity may occur only when the bending moment exceeds two thirds of the ultimate bending moment $M_{j, R d}$.

The moment resistance of the joint loaded by bending and axial forces can be expressed as function of axial force and resistance of components:

$$
M_{R d}=f\left(N, F_{R d, b w t}, F_{R d, b t}, F_{R d, e p b}, F_{R d, b f c}\right) .
$$

The forces in the components under tension or compression increase according to the axial force direction. It is necessary to notice that in some cases moment resistance of the joint can be less when axial force is not evaluated.

The moment resistance can by found by formulas (6), (7) and (11). For example, when both sides of the connection are in compression (Fig 3, c), $M_{R d}$ can be expressed by formula (6) using:

$$
M_{R d}=2 z_{c}\left(F_{R d, b f c}+\frac{N}{2}\right)
$$

where $F_{R d, b f c}$ - resistance of beam flange in compression.

\section{Numerical examples}

\section{Example 1.}

Beam-to-beam joint shown in Fig 4 is analysed. It is loaded by bending moments and axial forces or only by bending moments. Axial forces applied in compression or tension direction and their values are equal to $10 \%$ and $25 \%$ of ultimate value of axial load-bearing capacity of a joint.

The rigidity and strength characteristics of the joint (Fig 4) were obtained by the procedure in Chapter 4 . They were achieved according to the code on design of steel structures EC3 [7].

For comparable analysis, the calculations of the joint were made by the finite element method [14]. The joint deformations were obtained on the level of bolts under tension. Ratio of the total deformation on the level of bolts under tension and the lever arm allow to define the rotation angle $\Phi$.

Moment-rotation $M-\Phi-N$ curves for different values of axial forces are shown in Fig 5. The curves are ob-

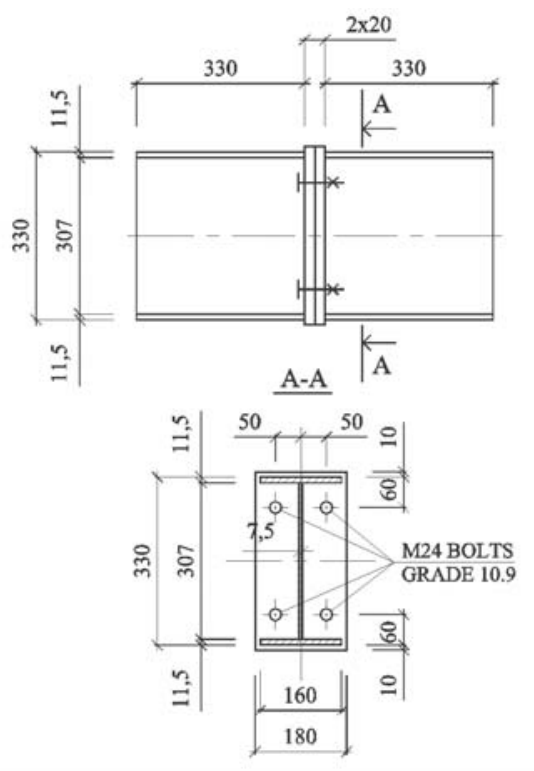

Fig 4. Beam-to-beam joint (measures in $\mathrm{mm}$ ): general view, section A-A 

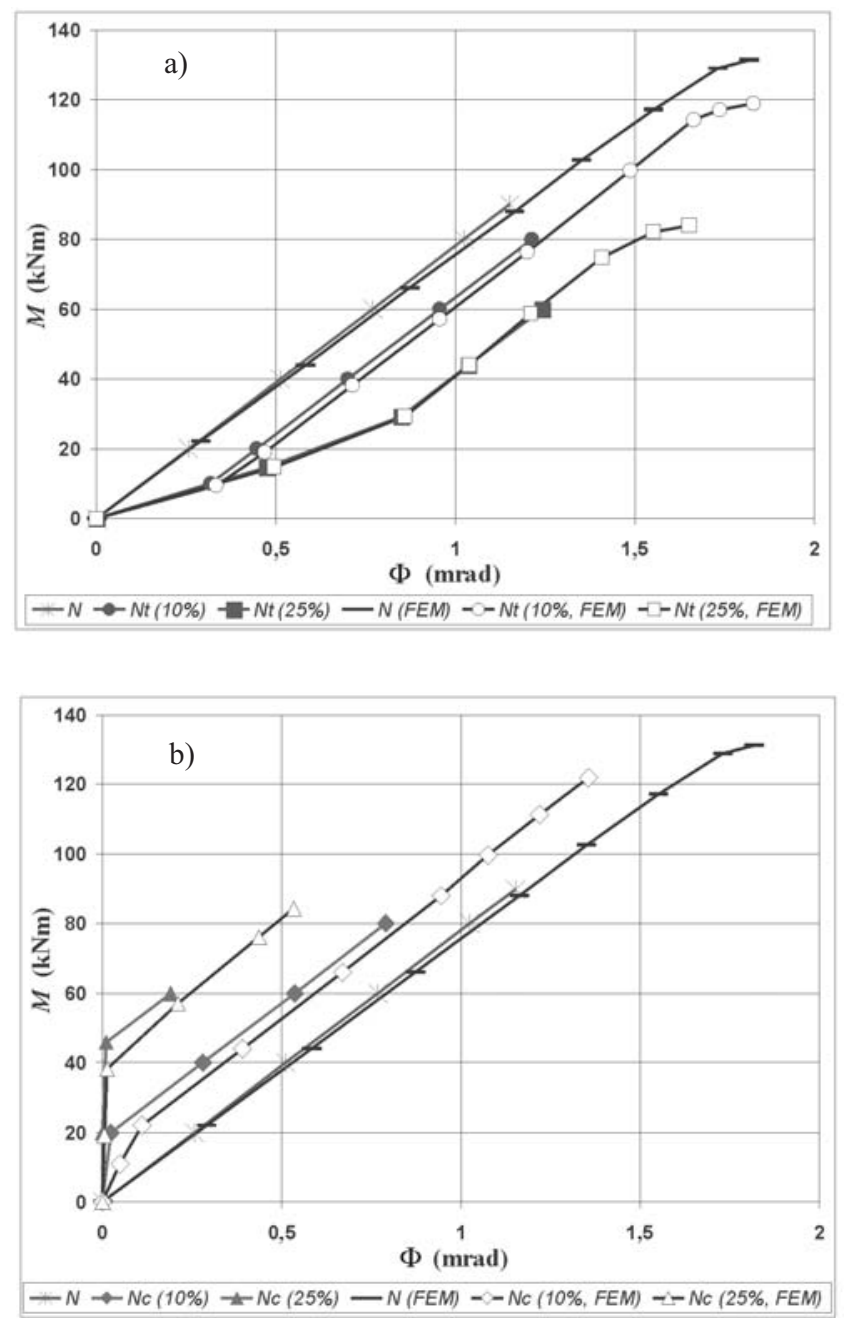

Fig 5. Moment-rotation $M-\Phi-N$ curves of beam-to-beam joint for different level of axial force: a) tension axial force; b) compression axial force

tained by calculations according to the presented procedure and by finite element method. $N$ in Fig 5 means axial force, index $c$ - compression, and index $t$ - tension. The percentage indicates the level of axial force compared to the joint axial load-bearing capacity. Curves marked with sign FEM are obtained by finite element method [14].

Results of beam-to-beam stiffness calculations according to the presented procedure and the results obtained according to the finite element method are very similar and their numerical values are very close (Fig 5). Major differences appear under the affect of compression force and relatively small values of bending moment.

Results of beam-to-beam moment resistance calculations according to the presented procedure and the results obtained according to the finite element method when the joint is loaded by bending moment and tension axial force or only by bending moment differing up to $15 \%$.

\section{Example 2.}

The beam-to-column knee joints shown in Fig 6 were analysed. The beams to columns are connected through the end-plates by bolts. The joint, as in example 1 , is loaded by bending moments and axial forces or only by bending moments. Axial forces applied in compression or tension direction and their values are equal to $10 \%$ and $25 \%$ of ultimate value of axial load-bearing capacity of a joint.
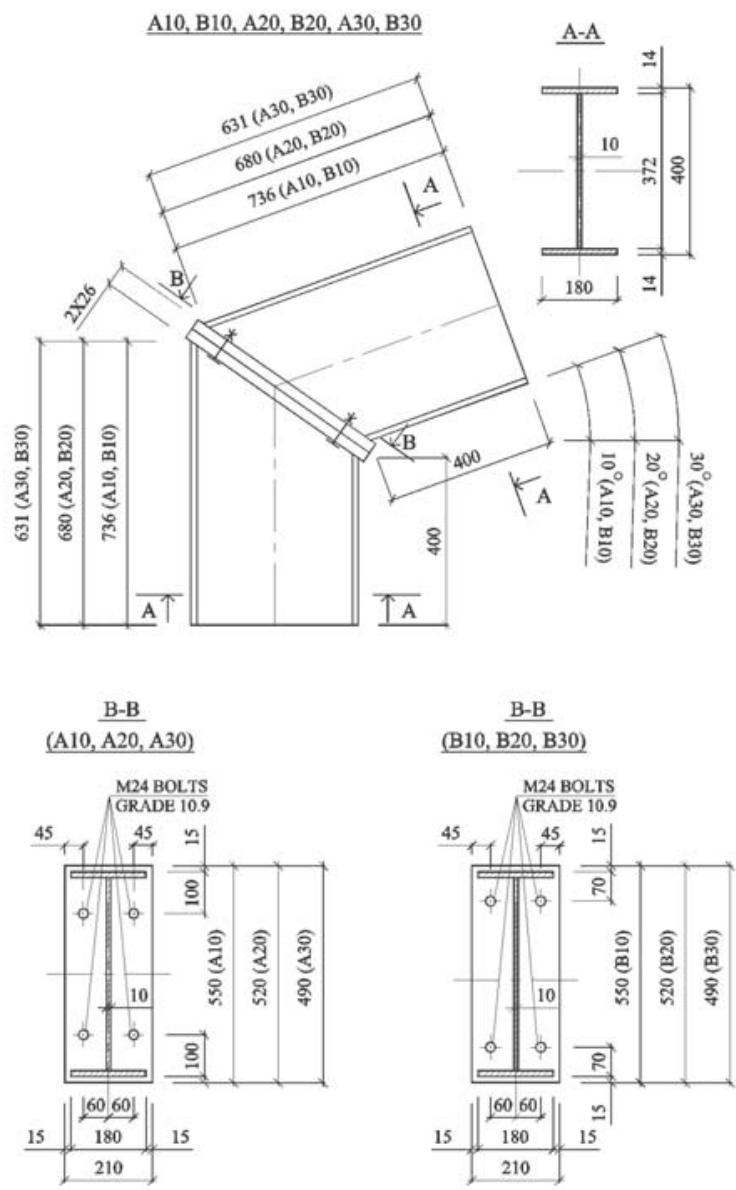

Fig 6. Beam-to-column knee joints details (mm): general view; section A-A; section B-B of joints A10, A20, A30; section B-B of joints B10, B20, B30

The rigidity and strength characteristics of this joint were obtained by calculation defined in Chapter 4 . Components were calculated by the methodology presented in codes EC3 and according to Faella [1,7].

Also, calculations of these joints were performed by finite element method when the joints are loaded by bending moments [15].

Moment-rotation $M-\Phi-N$ curves of beam-to-column knee joint B20 are shown in Fig 7.

The numerical results of calculations according to the presented procedure are in Table. The moment-rotation $M-\Phi-N$ curves obtained by finite element method 


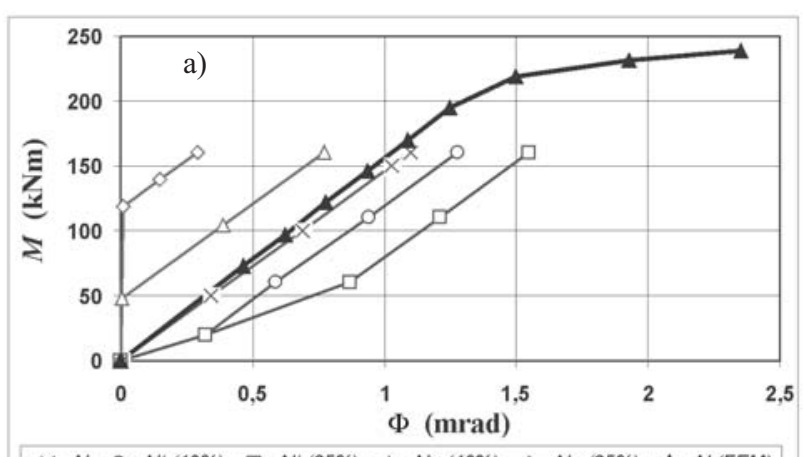

$-\times-N \multimap-N t(10 \%)-\square-N t(25 \%)-\triangle-N c(10 \%) \prec N c(25 \%) \rightarrow N($ FEM $)$

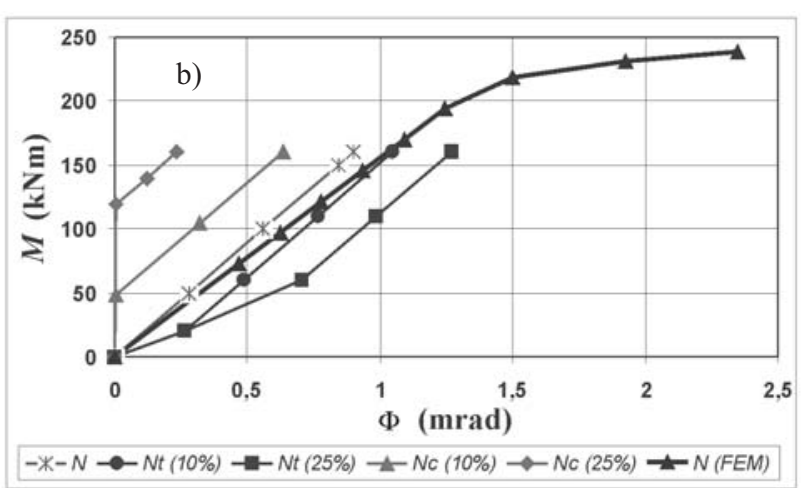

Fig 7. Moment-rotation $M-\Phi-N$ curves of beam-to-column knee joint B20 for different level of axial force: a) stiffness coefficients for components are calculated according to Faella; b) stiffness coefficients for components are calculated according to EC 3

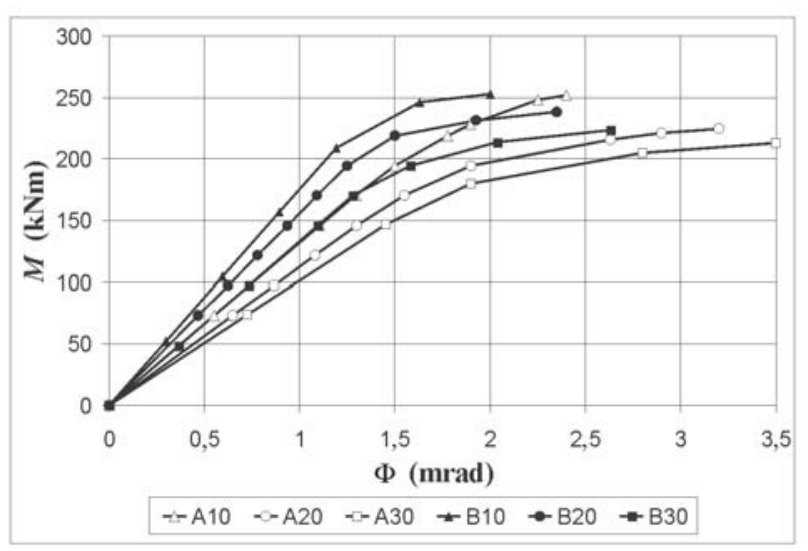

Fig 8. Moment-rotation $M-\Phi$ curves calculated by FEM of beam-to-column knee joints A10, A20, A30, B10, B20, B30

are in Fig 8. Beam-to-column knee joint stiffness calculations results according to Faella compared to EC3 have been closer to the results obtained by the finite element method. Rotation of joint loaded by bending moment when components were calculated by EC3 differs up to $30 \%$ and according Faella up to $8 \%$ compared to the results obtained by the finite element method.
Rotation $\Phi$ in mrad of beam-to-column knee joints (Fig 6). Case 1 - stiffness coefficients for components are calculated according EC 3. Case 2 - stiffness coefficients for components are calculated according to Faella

\begin{tabular}{|c|c|c|c|c|c|}
\hline $\begin{array}{c}\text { Calculations } \\
\text { of }\end{array}$ & \multicolumn{5}{|c|}{ Bending moment $M(\mathrm{kNm})$} \\
\hline \multicolumn{6}{|c|}{ Joint A10 } \\
\hline$N=0$ & $M=0$ & $M=50,0$ & $M=100,0$ & $M=150,0$ & $M=160,0$ \\
\hline Case 1 & 0 & 0,285 & 0,570 & 0,855 & 0,912 \\
\hline Case 2 & 0 & 0,350 & 0,701 & 1,051 & 1,121 \\
\hline Nt $(10 \%)$ & $M=0$ & $M=20,0$ & $M=50,0$ & $M=100,0$ & $M=160,0$ \\
\hline Case 1 & 0 & 0,271 & 0,442 & 0,727 & 1,069 \\
\hline Case 2 & 0 & 0,334 & 0,544 & 0,894 & 1,315 \\
\hline Nt (25\%) & $M=0$ & $M=20,0$ & $M=50,0$ & $M=100,0$ & $M=160,0$ \\
\hline Case 1 & 0 & 0,293 & 0,678 & 0,963 & 1,305 \\
\hline Case 2 & 0 & 0,360 & $\mathbf{0 , 8 3 4}$ & 1,184 & 1,605 \\
\hline$N c(10 \%)$ & $M=0$ & $M=53,0$ & $M=85,0$ & $M=130,0$ & $M=160,0$ \\
\hline Case 1 & $\mathbf{0}$ & 0,002 & 0,184 & 0,440 & 0,611 \\
\hline Case 2 & 0 & 0,002 & 0,226 & 0,542 & 0,752 \\
\hline$N c(25 \%)$ & $M=0$ & $M=132,0$ & $M=140,0$ & $M=160,0$ & \\
\hline $\begin{array}{l}\text { Case } 1 \\
\end{array}$ & 0 & 0,001 & 0,047 & 0,161 & \\
\hline Case 2 & 0 & 0,002 & 0,058 & 0,198 & \\
\hline \multicolumn{6}{|c|}{ Joint A20 } \\
\hline$N=0$ & $M=0$ & $M=50,0$ & $M=100,0$ & $M=150,0$ & \\
\hline Case 1 & 0 & 0,328 & 0,657 & 0,985 & \\
\hline Case 2 & 0 & 0,401 & 0,803 & 1,204 & \\
\hline$N t(10 \%)$ & $M=0$ & $M=20,0$ & $M=50,0$ & $M=100,0$ & $M=150,0$ \\
\hline Case 1 & 0 & 0,306 & 0,503 & 0,831 & 1,159 \\
\hline Case 2 & 0 & 0,374 & 0,615 & 1,016 & 1,417 \\
\hline$N t(25 \%)$ & $M=0$ & $M=20,0$ & $M=50,0$ & $M=100,0$ & $M=150,0$ \\
\hline Case 1 & 0 & 0,344 & 0,760 & 1,089 & 1,417 \\
\hline Case 2 & 0 & 0,421 & 0,930 & 1,331 & 1,733 \\
\hline$N c(10 \%)$ & $M=0$ & $M=50,0$ & $M=100,0$ & $M=150,0$ & \\
\hline Case 1 & 0 & 0,020 & 0,348 & 0,676 & \\
\hline Case 2 & 0 & 0,024 & 0,426 & 0,827 & \\
\hline Nc $(25 \%)$ & $M=0$ & $M=118,0$ & $M=134,0$ & $M=150,0$ & \\
\hline Case 1 & 0 & 0,003 & 0,108 & 0,213 & \\
\hline Case 2 & 0 & 0,004 & 0,132 & 0,261 & \\
\hline \multicolumn{6}{|c|}{ Joint A30 } \\
\hline$N=0$ & $M=0$ & $M=50,0$ & $M=100,0$ & $M=150,0$ & \\
\hline Case 1 & 0 & 0,390 & 0,779 & 1,169 & \\
\hline Case 2 & 0 & 0,480 & 0,960 & 1,439 & \\
\hline$N t(10 \%)$ & $M=0$ & $M=20,0$ & $M=50,0$ & $M=100,0$ & $M=150,0$ \\
\hline Case 1 & 0 & 0,346 & 0,580 & 0,970 & 1,359 \\
\hline Case 2 & 0 & 0,426 & 0,714 & 1,194 & 1,674 \\
\hline Nt $(25 \%)$ & $M=0$ & $M=20,0$ & $M=50,0$ & $M=100,0$ & $M=150,0$ \\
\hline Case 1 & 0 & 0,422 & 0,865 & 1,255 & 1,645 \\
\hline Case 2 & 0 & 0,520 & 1,066 & 1,545 & 2,025 \\
\hline$N c(10 \%)$ & $M=0$ & $M=45,0$ & $M=97,5$ & $M=150,0$ & \\
\hline Case 1 & 0 & 0,005 & 0,414 & 0,823 & \\
\hline Case 2 & 0 & 0,006 & 0,510 & 1,013 & \\
\hline Nc $(25 \%)$ & $M=0$ & $M=111,0$ & $M=135,5$ & $M=150,0$ & \\
\hline Case 1 & 0 & 0 & 0,191 & 0,304 & \\
\hline Case 2 & 0 & 0 & 0,235 & 0,374 & \\
\hline \multicolumn{6}{|c|}{$\begin{array}{l}\text { Joint B10 } \\
\end{array}$} \\
\hline$N=0$ & $M=0$ & $M=50,0$ & $M=100,0$ & $M=150,0$ & $M=160,0$ \\
\hline Case 1 & 0 & 0,244 & 0,488 & 0,731 & 0,780 \\
\hline Case 2 & 0 & 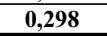 & 0,596 & 0,894 & 0,954 \\
\hline$N t(10 \%)$ & $M=0$ & $M=20,0$ & $M=60,0$ & $M=110,0$ & $M=160,0$ \\
\hline Case 1 & 0 & 0,226 & 0,431 & 0,675 & 0,918 \\
\hline Case 2 & 0 & 0,277 & 0,527 & 0,825 & 1,123 \\
\hline Nt (25\%) & $M=0$ & $M=20,0$ & $M=60,0$ & $M=110,0$ & $M=160,0$ \\
\hline Case 1 & 0 & 0,226 & 0,635 & 0,879 & 1,123 \\
\hline Case 2 & 0 & 0,277 & 0,777 & 1,075 & 1,373 \\
\hline Nc $(10 \%)$ & $M=0$ & $M=54,0$ & $M=107,0$ & $M=160,0$ & \\
\hline Case 1 & 0 & 0,004 & 0,262 & 0,521 & \\
\hline Case 2 & 0 & 0,005 & 0,321 & 0,637 & \\
\hline$N c(25 \%)$ & $M=0$ & $M=134,0$ & $M=147,0$ & $M=160,0$ & \\
\hline Case 1 & 0 & 0,005 & 0,068 & 0,132 & \\
\hline Case 2 & 0 & 0,006 & 0,083 & 0,161 & \\
\hline
\end{tabular}




\begin{tabular}{|c|c|c|c|c|c|}
\hline \multicolumn{6}{|c|}{ Joint B20 } \\
\hline$N=0$ & $M=0$ & $M=50,0$ & $M=100,0$ & $M=150,0$ & $M=160,0$ \\
\hline Case 1 & $\mathbf{0}$ & 0,281 & 0,561 & 0,842 & 0,898 \\
\hline Case 2 & $\mathbf{0}$ & 0,343 & 0,686 & 1,029 & 1,098 \\
\hline Nt $(10 \%)$ & $\mathrm{M}=0$ & $\mathrm{M}=20,0$ & $\mathrm{M}=60,0$ & $\mathrm{M}=110,0$ & $M=160,0$ \\
\hline Case 1 & $\mathbf{0}$ & 0,262 & 0,487 & 0,767 & 1,048 \\
\hline Case 2 & $\mathbf{0}$ & $\mathbf{0 , 3 2 0}$ & 0,595 & 0,938 & 1,281 \\
\hline$N t(25 \%)$ & $M=0$ & $M=20,0$ & $M=60,0$ & $M=110,0$ & $M=160,0$ \\
\hline Case 1 & $\mathbf{0}$ & 0,264 & 0,708 & 0,988 & 1,269 \\
\hline Case 2 & $\mathbf{0}$ & 0,322 & 0,865 & 1,208 & 1,552 \\
\hline$N c(10 \%)$ & $M=0$ & $M=48,0$ & $M=104,0$ & $M=160,0$ & \\
\hline Case 1 & 0 & 0,004 & 0,319 & 0,633 & \\
\hline Case 2 & $\mathbf{0}$ & 0,005 & 0,390 & 0,774 & \\
\hline$N c(25 \%)$ & $M=0$ & $M=119,0$ & $M=139,5$ & $M=160,0$ & \\
\hline Case 1 & $\mathbf{0}$ & 0,006 & 0,121 & 0,236 & \\
\hline Case 2 & 0 & 0,007 & 0,148 & 0,288 & \\
\hline \multicolumn{6}{|c|}{ Joint B30 } \\
\hline$N=0$ & $M=0$ & $M=50,0$ & $M=100,0$ & $M=150,0$ & \\
\hline Case 1 & $\mathbf{0}$ & 0,325 & 0,650 & 0,975 & \\
\hline Case 2 & $\mathbf{0}$ & $\mathbf{0 , 3 9 7}$ & 0,794 & 1,192 & \\
\hline Nt $(10 \%)$ & $M=0$ & $M=20,0$ & $M=50,0$ & $M=100,0$ & $M=150,0$ \\
\hline Case 1 & $\mathbf{0}$ & 0,293 & 0,488 & 0,813 & 1,138 \\
\hline Case 2 & 0 & 0,358 & $\mathbf{0 , 5 9 7}$ & 0,994 & 1,391 \\
\hline$N t(25 \%)$ & $M=0$ & $M=20,0$ & $M=50,0$ & $M=100,0$ & $M=150,0$ \\
\hline Case 1 & $\mathbf{0}$ & 0,310 & 0,729 & 1,054 & 1,379 \\
\hline Case 2 & $\mathbf{0}$ & 0,379 & 0,891 & 1,288 & 1,686 \\
\hline$N c(10 \%)$ & $M=0$ & $M=45,0$ & $M=97,5$ & $M=150,0$ & \\
\hline Case 1 & $\mathbf{0}$ & $\mathbf{0 , 0 0 1}$ & 0,342 & 0,683 & \\
\hline Case 2 & $\mathbf{0}$ & 0,001 & 0,418 & 0,835 & \\
\hline$N c(25 \%)$ & $M=0$ & $M=113,0$ & $M=131,5$ & $M=150,0$ & \\
\hline Case 1 & $\mathbf{0}$ & 0,006 & 0,126 & 0,246 & \\
\hline Case 2 & 0 & 0,007 & 0,154 & 0,301 & \\
\hline
\end{tabular}

The moment resistance calculations results according to EC3 and Faella are equal. Moment resistance calculations results according to the presented procedure and the results obtained by the finite element method when the joint is loaded by bending moment differ up to $8 \%$

\section{Conclusions}

In the paper, the evaluation procedure of rigidity and strength of beam-to-beam end-plate and beam-tocolumn knee end-plate joints loaded by bending moment and axial force was presented.

The presented procedure allows the well-known component method, which is adopted for stiffness and strength calculation of various types of joints loaded by bending moment, extends the computation of joint stiffness and strength taking into account bending moment and axial force.

The rigidity depends on the values and directions of acting forces. The results obtained show that tension axial forces decrease the rigidity of joints, but compression axial forces increase it. If the tension axial force is equal to $10 \%$ and $25 \%$ of axial load-bearing capacity of a joint, then the rigidity of joint decreases approximately up to $15 \%$ and $50 \%$ respectively. Consequently, the results evidence the need to take into account axial force actually less than $10 \%$ of axial load-bearing capacity.

The compound moment-rotation $M-\Phi-N$ curves of beam-to-column knee joint indicates that the rigidity of joint increases the beam angle and the level contour decreases.

\section{References}

1. Faella, C.; Piluso, V.; Rizzano, G. Structural steel semirigid connections: theory, design and software. Boca Raton: CRC Press LLC, 2000. 494 p.

2. Chen, W. F.; Goto, Y.; Liew, J. Y. R. Stability design of semi-rigid frames. John Wiley \& Sons, 1996. 468 p.

3. van Keulen, D. C; Nethercot, D. A.; Snijder, H. H.; Bakker, M. C. M. Frames analysis incorporating semi-rigid joint action: Applicability of the half initial Secant stiffness approach. Journal of Constructional Steel Research, 2003, Vol 59, p. 1083-1100.

4. Jaspart, J. P. General report: session on connections. Journal of Constructional Steel Research, 2000, Vol 55, p. 6989.

5. Hasan, R.; Kishi, N.; Chen, W.-F. A new nonlinear connections classification system. Journal of Constructional Steel Research, 1998, Vol 47, p. 119-140.

6. Wilkinson, T.; Hancock, G. J. Tests to examine plastic behaviour of knee joints in cold-formed RHS. Journal of Structural Engineering, 2000, Vol 126, No 3, p. 297-305.

7. Revised Annex J of Eurocode 3. Joints in building frames, European Prestandard ENV 1993-1-1:1992/A2:1998, CEN Brussels, Belgium.

8. Eurocode 3. Design of steel structures. Part 1.1: General Rules and Rules for Buildings, European Prestandard ENV 1993-1-1:1992, CEN Brussels, Belgium.

9. de Lima, L. R. O.; da Silva, L. S.; da S. Vellasco, P. C. G.; de Andrade, S. A. L. Experimental analysis of extended end-plate beam-to-column joints under bending and axial force. Eurosteel Coimbra, 2002, p. 1121-1130.

10. Cerfontaine, F.; Jaspart, J. P. Analytical study of the interaction between bending and axial force in bolted joints. Eurosteel Coimbra, 2002, p. 997-1006.

11. Sokol, Z.; Wald, F.; Delabre, V.; Muzeau, J. P.; Švarc, M. Design of end plate joints subject to moment and normal force. Eurosteel Coimbra, 2002, p. 1219-1228.

12. Jaspart, J. P.; Weynand, K. Extension of the component method to joints in tubular construction. In: Proceedings of the Ninth International Symposium and Euroconference on tubular structures. Düsseldorf, 2001, p. 517-523.

13. Weynand, K.; Jaspart, J. P.; Steenhuis M. The stiffness model of revised Annex J of Eurocode 3. In: Proceedings of the third international workshop on connections in steel structures behaviour, strength and design. Trento, 1995, p. $441-452$.

14. Urbonas, K.; Daniūnas, A. Behaviour of steel beam-tobeam connections under bending and axial force. In: Proc. of the 8th international conference "Modern building materials, structures and techniques". Selected papers. Edited by E. K. Zavadskas, P. Vainiūnas and F. M. Mazzolani. Vilnius: Technika, 2004, p. 650-653.

15. Urbonas, K.; Daniūnas, A. Numerical tests of steel beamto-column semi-rigid connections. Journal of Civil Engineering and Management, 2003, Vol 9, No 4, p. 292-296. ISSN 1392-3730. 

KOMPONENTU METODO TAIKYMAS SIJÜ-SIJU IR ALKŪNINIAMS SIJÜ-KOLONŲ SU GALINE
PLOKŠTELE MAZGAMS, VEIKIAMIEMS LENKIMO MOMENTO IR AŠINĖS JĖGOS

\section{K. Urbonas, A. Daniūnas}

Santrauka

Nagrinejjami pusiau standūs sijų-sijų su galine plokštele ir alkūniniai sijų-kolonų su galine plokštele varžtiniai mazgai, veikiami lenkimo momento ir ašinės jẻgos. Teigiama, kad ašinès jẻgos itaka mazgo standumui yra nežymi. Pagal EC3 ašinè jèga, mažesnè nei $10 \%$ nuo plastinio sujungiamų elementų atsparumo ašinei jègai, projektuojant mazgą gali būti nevertinama. Realiai ašinès jègos dydis konstrukcijų kai kurių tipų mazguose gali būti reikšmingas ir turèti didelès ịtakos mazgo standumui bei stiprumui. Vienas iš populiariausių praktinių metodų, leidžiančių nustatyti mazgo standumą ir stiprumą, vertinant tik lenkimo momento itaką, yra komponentų metodas. Pateiktas šio metodo taikymas mazgu standumui ir stiprumui skaičiuoti, ivvertinant lenkimo momento ir ašinės jẻgos poveikị. Pateikti sijų-sijų su galine plokštele ir alkūninių sijų-kolonų su galine plokštele mazgų skaičiavimo rezultatai.

Raktažodžiai: plieninès konstrukcijos, pusiau standūs mazgai, sijos-sijos mazgas, sijos-kolonos alkūninis mazgas, lenkimo momentas ir ašinè jẻga, komponentų metodas, momento-pasisukimo kreivé, stiprumas.

Kęstutis URBONAS. MSc, PhD student in Dept of Steel and Timber Structures, Vilnius Gediminas Technical University, Vilnius, Lithuania. Research interests: steel structures, semi-rigid joints, strength and stiffness of steel semi-rigid joints.

Alfonsas DANIŪNAS. Doctor, Assoc Professor in Dept of Steel and Timber Structures, Vilnius Gediminas Technical University, Vilnius, Lithuania. Research interests: analysis and optimization of elastic-plastic systems, application to steel structures, semi-rigid joints. 